\title{
Pierre Teilhard de Chardin: Critical Reflections
}

\author{
H. James Birx \\ University of Belgrade, Faculty of Philology, Studentski trg 3, 11000 Belgrade, Serbia \\ Canisius College, Anthropology Division, 2001 Main Street, Buffalo, New York 14208-1098 USA
}

Received $9^{\text {th }}$ December 2014; accepted $26^{\text {th }}$ February 2015

\section{PIERRE TEILHARD DE CHARDIN: KRITICKÁ ZAMYŠLENÍ}

ABSTRAKT Geopaleontolog a jezuitský kněz Pierre Teilhard de Chardin se směle pokusil sloučit osobního Boha a kosmickou evoluci do unikátního filozofického světonázoru, jenž uznává hodnotu vědy i teologie. Vycházeje ze svých vlastních zamyšlení a zkušeností, nabídl obsáhlou a sjednocenou interpretaci skutečnosti založenou na čtyřech základních myšlenkách: pronikající duch, zákon komplexity-vědomí, kritické hranice, a budoucí Bod Omega. Výsledkem je dynamický panenteismus, který v rámci planetární historie přikládá lidské existenci zvláštní význam a zároveň obhajuje mystickou jednotu našeho druhu s Bohem-Omega na konci lidské evoluce na Zemi.

KLÍČOVÁ SLOVA konvergence; evoluce; Bůh-Omega; humanismus; mysticismus; Bod Omega; věda; teleologie; teologie; ultra-antropologie

ABSTRACT The geopaleontologist and Jesuit priest Pierre Teilhard de Chardin made a bold attempt to synthesize a personal God and cosmic evolution into a unique philosophical worldview that acknowledged the value of both science and theology. Drawing from his own reflections and experiences, he offered a comprehensive and integrated interpretation of reality grounded in four major ideas: pervasive spirit, the law of complexity-consciousness, critical thresholds, and a future Omega Point. The outcome is a dynamic panentheism that gives both a special place to human existence within planetary history and argues for a mystical unity of our species with God-Omega at the end of human evolution on the earth.

KEY WORDS convergence; evolution; God-Omega; humanism; mysticism; Omega Point; science; teleology; theology; ultra-anthropology

\section{INTRODUCTION}

An anthropologist as evolutionist may ask this quintessential three-part question about Homo sapiens sapiens: Where did our own species come from, what is its unique nature, and where is it going?

Ever since the groundbreaking writings of naturalist Charles Darwin (1809-1881), serious scientists and philosophers and theologians have grappled with the far-reaching consequences of accepting the factual theory of organic evolution. Darwin's conceptual revolution in terms of biology and history not only challenged the embedded Aristotelian philosophy and Thomistic theology, but also offered an alarming new scientific view of both life on earth and the place of humankind within this universe. Nothing escapes the pervasive influence of this evolutionary worldview. Although interpretations of evolution do differ from thinker to thinker, the brute fact of organic evolution in general and human evolution in particular can no longer be ignored by any enlightened individual; the ramifications of evolution have resulted in new ideas in science and new beliefs in theology. Evolution has resulted in an all-encompassing process philosophy that now envelopes the modern intellectual framework, ranging from cosmology to anthropology.

But, are science and theology reconcilable in terms of evolution? As an eminent scientist and cosmic mystic, Pierre Teilhard de Chardin (1881-1955) presented a dynamic worldview in which he argued that our species does occupy a special place within a spiritual universe and that it is evolving toward an Omega Point as the end-goal of humankind on this planet. With his commitment to the fact of evolution, Teilhard as both geopaleontologist and Jesuit priest became a 


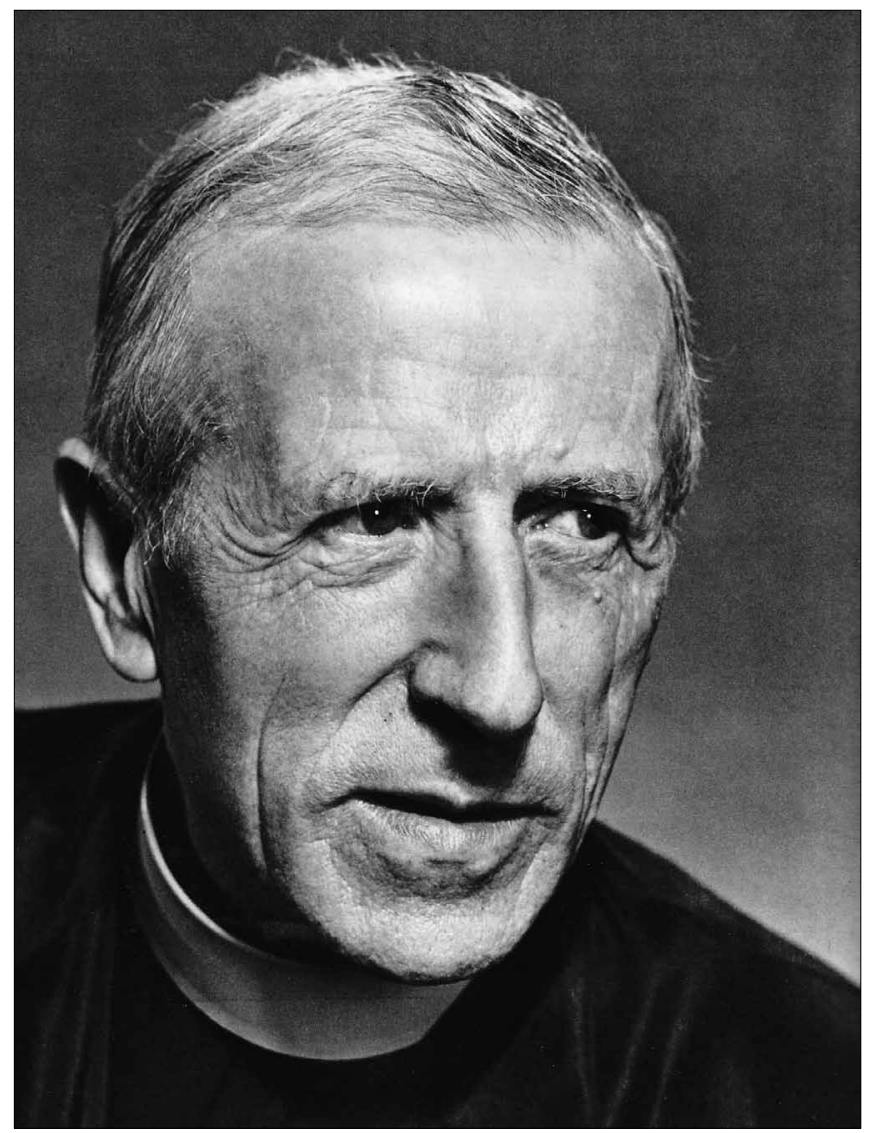

Fig. 1. Pierre Teilhard de Chardin (portrait).

very controversial figure within the Roman Catholic Church during the first half of the 20th century. Actually, because of his bold interpretation of our species within not only earth history, but also a dynamic universe, he was silenced by his Jesuit superiors for taking an evolutionary stance at a time when this theory was a threat to the entrenched orthodox theology. A modern-day religious humanist, Teilhard maintained that his theistic evolution still discloses the special place our species occupies within life, nature, and this cosmos.

As a geopaleontologist, Teilhard was familiar with the rock and fossil evidence that substantiated the fact of evolution. As a Jesuit priest, he was acutely aware of the need for a meta-Christianity that would contribute to the survival and fulfillment of humankind on this planet in terms of both science and faith. Sensitive to the existential predicament of our species with its awareness of endless space and certain death, Teilhard as visionary and futurist ultimately grounded his personal interpretation of evolution in a process philosophy, natural theology, and cosmic mysticism that supported panentheism (the belief that God and the World are in a creative relationship of progressive evolution). Galileo was put under house arrest, and endured humiliation, as a result of his claim that the earth does in fact move through the universe; a discovery that the aged astronomer was coerced into recanting by the dogmatic Pope Urban VIII (formally Cardinal Maffeo Barberini). Disappointed in the conservative and narrow standpoint taken by his Jesuit superiors, Teilhard suffered alienation and discouragement because he rightly claimed that species (including our own) evolve throughout geological time.

On 1 May 1881, Teilhard was born at the Chateau Sarcenat in Orcines, France, near the beautiful volcanic hills of Auvergne. His father was an avid naturalist and his mother was a devout religionist. Throughout his life, Teilhard would remain devoted to both science and theology; he had a deep and lasting desire to present an ultra-anthropology (as he put it) that included both the facts of evolution and the beliefs of Christianity.

As a child, Teilhard showed an interest in both natural science and religious mysticism. Sensitive to his surroundings, he was particularly drawn to the study of rocks and fossils, as well as to collecting insects and minerals. Within this changing world, he began searching for something indestructible and eternal; he found delight in a plowshare (his "genie of iron") which he supposed was an enduring object free from change and imperfection. However, after a storm, the youth discovered that his piece of iron had rusted. Teilhard tells us that he then threw himself on the ground and cried with the bitterest tears of his life. As a result of this devastating experience, he would have to seek his "one essential thing" beyond this imperfect world of matter and corruption. In 1899, to be "most perfect" (as he put it), Teilhard at the age of 17 entered the Jesuit society as a novitiate in order to serve God. Nevertheless, he intensified his interest in geology on the channel island of Jersey. Throughout his entire life, the scientist-priest would never abandon his love for science, philosophical outlook, and devotion to theology (especially eschatology).

\section{EVOLUTION \& MYSTICISM}

In 1905, as part of his religious training, Teilhard found himself teaching at the Jesuit College of the Holy Family in Cairo, Egypt. This unique three-year experience offered him the opportunity to do research in both geology and paleontology, expanding his knowledge of earth history. It also exposed him to a rich multiplicity of cultures, both in the past and the present, which surely jarred him from European ethnocentrism. Following this teaching obligation, he finished his theology studies at Hastings in England. It was during his stay in England that Teilhard read Henri Bergson's major book, Creative Evolution (1907). This metaphysical work had an enormous influence on Teilhard, since it resulted in his lifelong commitment to the fact of evolution. It is worth emphasizing that it was not Charles Darwin's On the Origin of Species (1859) but rather Bergson's interpretation of evolution that convinced the scientist-priest that species are mutable throughout organic history; Teilhard was sympathetic to Bergson's philosophical vitalism, rather than to Darwin's scientific materialism. Also of significance is the fact that, in the nineteenth century, after the views of Lamarck, no spokesperson like Thomas Huxley in England and Ernst Haeckel in Germany had been as committed as they were to defending the evolution framework in France. 


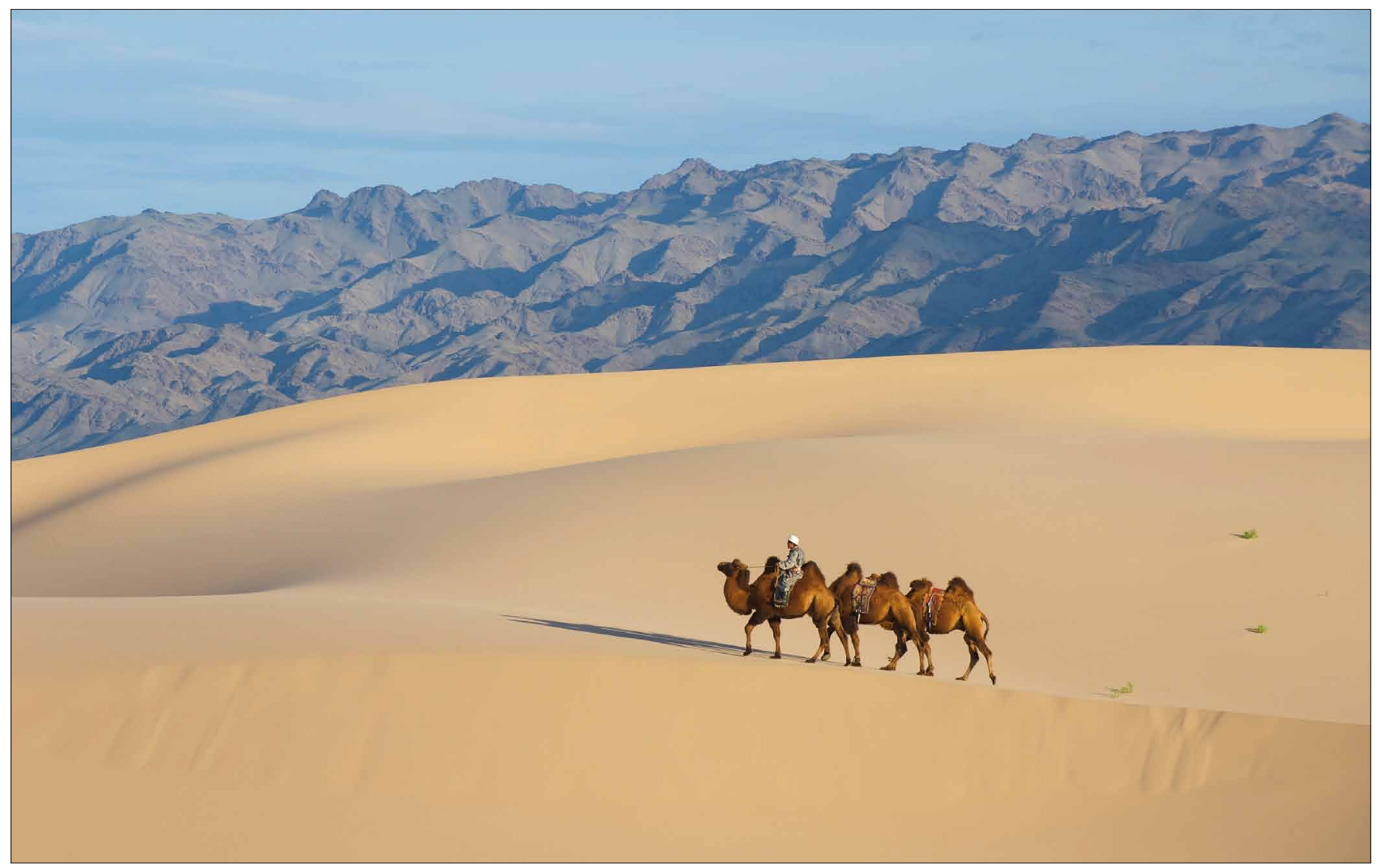

Fig. 2. Mongolia.

On 24 August 1911, at the age of 30, Teilhard was ordained a priest; he would spend the rest of his life in the Jesuit Society as a geopaleontologist dedicated to both science and theology in terms of evolution.

While on one of his field trips, Teilhard by chance became involved in the discovery of the controversial Piltdown skull (later determined to be a fraud). Although questioning the validity of this fossil evidence from the very beginning, one positive result was that the young geologist and seminarian now became particularly interested in paleoanthropology as the science of fossil hominids. After his stay in England, Teilhard returned to France where, during World War I, he was a stretcher-bearer in the battle trenches at the front lines. It is remarkable that he emerged from his horrific experiences in the war even more optimistic that evolution was preparing the earth for a new direction and final goal in terms of the spiritualization of the human layer of this planet. In fact, during the global war, Teilhard had three mystical experiences which he recorded for posterity (Teilhard 1965, 41-55). It was his emerging mystical vision that would allow him to reconcile science and theology within an evolutionary interpretation of spiritual reality (as he saw it).

At the Natural History Museum in Paris, Teilhard studied under the geopaleontologist Marcellin Boule and completed his doctorate degree in paleontology with a thesis on the lower Eocence mammals and their stratigraphy in France. At this time, he befriended the prehistorian expert Abbe Henri Breuil, a research specialist on cave art, e.g., the exquisite wall murals of Lascaux in France and Altamira in Spain. These Cro-Magnon paintings of large animals remain one of the most significant discoveries of the creative activity of early Homo sapiens. Yet, how dearly would one love to discover also the portrait of an adult Cro-Magnon person!

In 1923, as a result of an invitation, Teilhard next found himself as a geologist participating in an expedition into western Mongolia. A year in China had given the young scientist a splendid opportunity to begin his career as a specialist in Chinese geology; this research was later supplemented with an intense interest in human paleontology. He was becoming more and more aware of deep space and deep time. It was during this period that, while in the Ordos desert of Mongolia, Teilhard delivered "The Mass on the World" $(1915,1923)$, a superb mystical account of his offering up the whole world as a Eucharist to a Supreme Being as the creator, sustainer, and ultimate destiny of an evolving universe. He expresses his emerging cosmic vision of Christ when he writes: "I, your priest, will make the whole earth my altar and on it will offer you all the labors and sufferings of the world... You know how your creatures can come into being only, like shoot from stem, as part of an endlessly renewed process of evolution" (Teilhard 1965, pp. 19, 22).

In 1924, the anatomist Raymond A. Dart had correctly inter- 


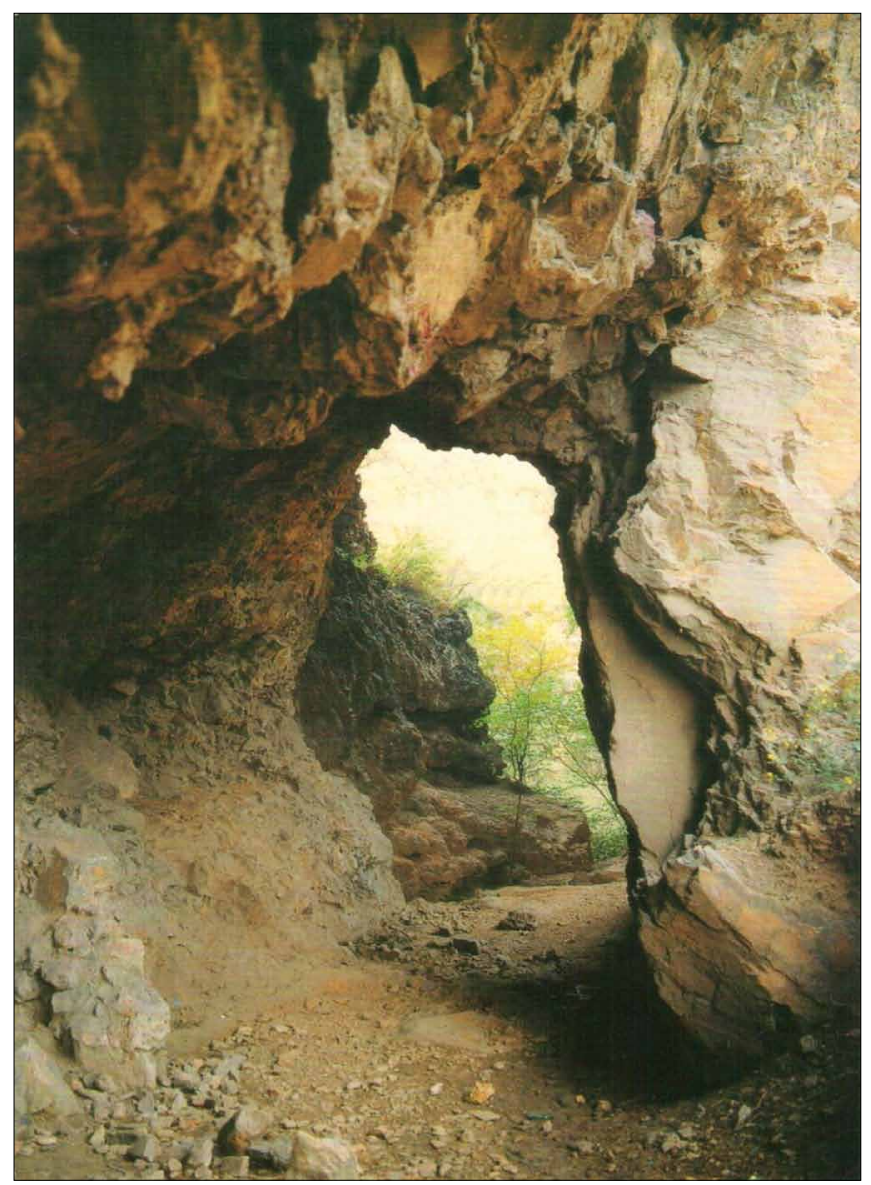

Fig. 3. Cave Entrance (Dragon Bone Hill).

preted the fossil primate juvenile skull from the Taung site in the Transvaal area of South Africa as belonging to a true hominid form. He classified it as Australopithecus africanus (one of several bipedal hominids living between 4-1 million years ago in Africa). Ironically, in 1925, the so-called John Scopes "monkey trial" took place in Dayton, Tennessee. No doubt, biblical fundamentalists were threatened by the growing evidence for both organic evolution and the emergence of the human animal from a fossil apelike form in the remote past. It is to Teilhard's credit that he never took seriously a strict and literal interpretation of Genesis as presented in the Old Testament of the Holy Bible. Instead, he was devoting his life to synthesizing science and theology in terms of the indisputable fact of pervasive evolution. Furthermore, his concern for the survival and fulfillment of our species on earth was expressed in his adherence to a unique synthesis of God and evolution that embraced a global religious humanism.

The more paleoanthropologists search, the more fossil hominid specimens they find in the rock strata of both central and south Africa. During the last decades, scientists have unearthed several different hominid species and, no doubt, more fossil hominid specimens are very likely to be discovered. Even so, this general evolutionary sequence has emerged: from Homo habilis, through Homo erectus, to Homo sapiens. This empirical evidence clearly shows a steady increase in cra-

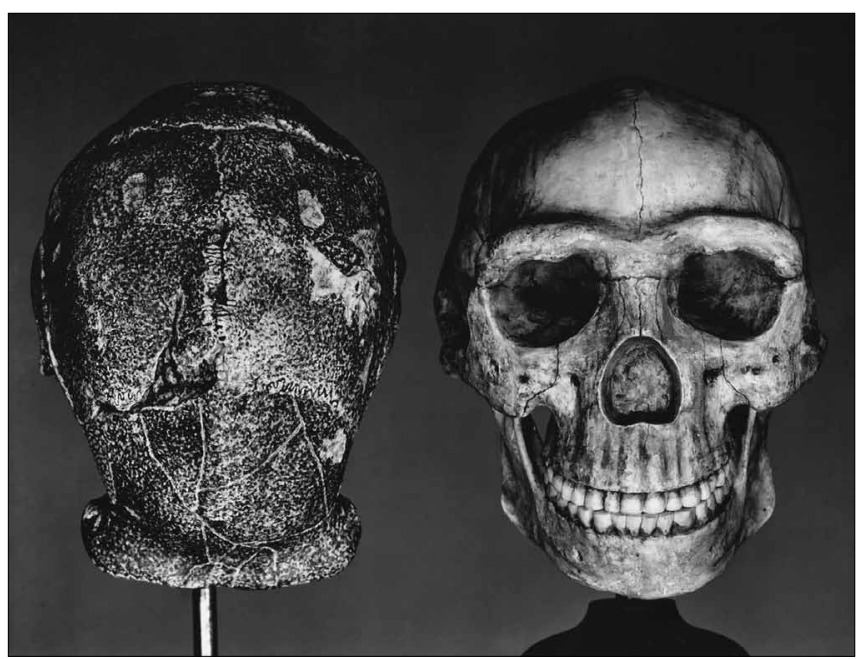

Fig. 4. Sinanthropus (skull).

nial capacity and eventually the divergence of some hominid populations out of Africa and throughout first the eastern hemisphere and then later the western hemisphere as well. Today, the species Homo sapiens has literally spread itself over the surface of this planet.

Returning to France, Teilhard ran into serious problems, in the eyes of the Roman Catholic Church, because of his unorthodox beliefs. In Paris, he began giving public lectures on and teaching about the fact of biological evolution. Teilhard was even bold enough to offer a personal interpretation of Original Sin and the problem of evil in terms of cosmic evolution and the emergence of our own species in a dynamic but imperfect (unfinished) universe; he saw the cosmos as a cosmogenesis moving from chaos and evil to order and perfection. When a copy of his controversial essay fell into the hands of some Jesuits, Teilhard was immediately silenced by his superiors. They, of course, had a failure of nerve in not facing head-on the fact of evolution and its ramifications for understanding and appreciating the place of humankind within nature. Because his controversial vision challenged Christian orthodoxy, Teilhard was censored by the Roman Catholic Church: he was forbidden to teach or publish his own theological and philosophical views. Yet, he would be allowed to publish the results of this extensive scientific research in historical geology.

And because of his commitment to evolution, Teilhard was even 'exiled' from France by the Jesuit order, finding himself sent back to China. He joined the Jesuit priest Emile Licent at his museum in Tientsin. During this time, the ostracized scientist-priest wrote his first book, The Divine Milieu (19261927), a spiritual essay on the activities and passivities of the human being. In it, he argues that a personal God is the divine Center of evolving Creation (in sharp contrast to viewing the entire universe as a completed event that happened only about six thousand years ago): "We may, perhaps, imagine that the creation was finished long ago. But that would be quite wrong. It continues still more magnificently, and at the highest levels of the world" (Teilhard 2001, 25). 


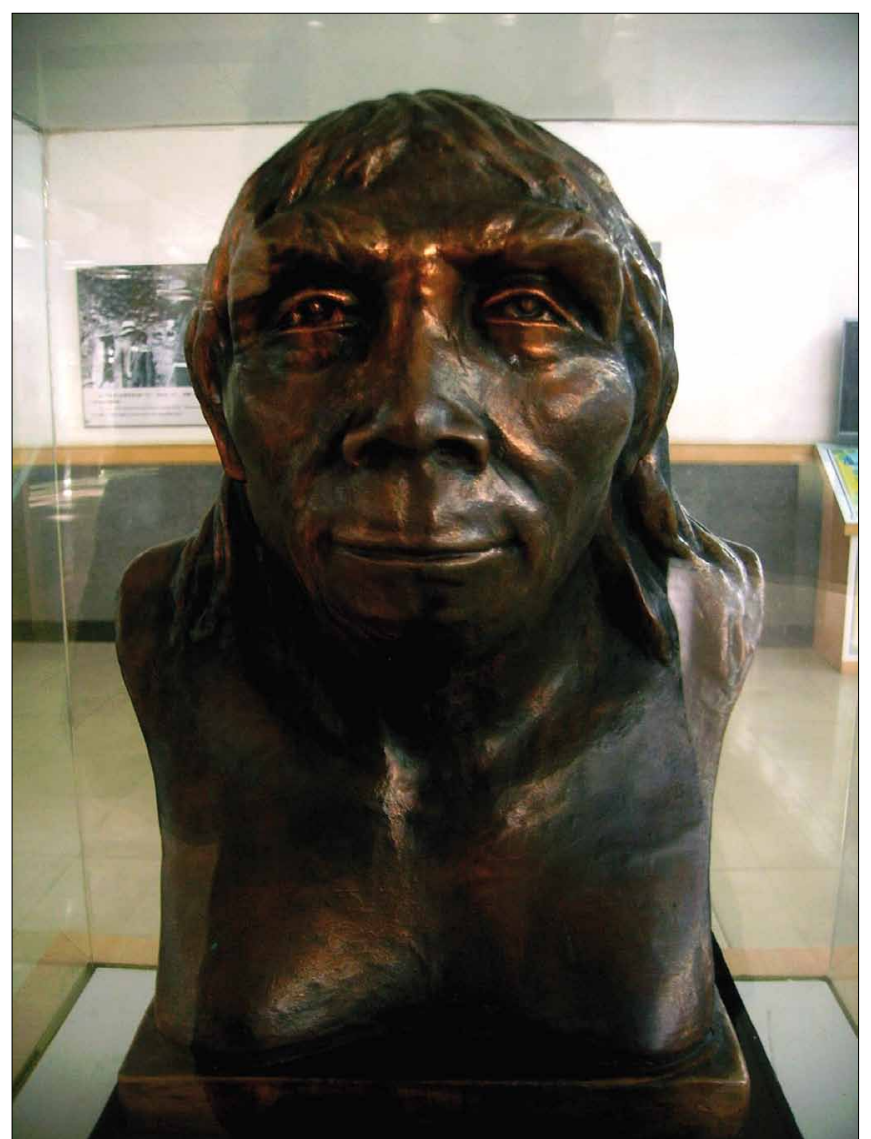

Fig. 5. Sinanthropus (sculpture).

Although avoiding the tempting position of pantheism, Teilhard did write: "God reveals himself everywhere, beneath our groping efforts, as a universal milieu, only because he is the ultimate point upon which all realities converge... God is infinitely near, and dispersed everywhere" (Teilhard 2001, 85). In his later thought, he developed the idea of God-Omega as the goal of human evolution.

Fortuitously, Teilhard now found himself a member of the Cenozoic Research Laboratory at the Peking Union Medical College. He was the chief geological specialist on the excavation research team at Dragon Bone Hill (Longgushan) in the Western Hills near the village of Zhoukoudian. Starting in 1928, geologists and paleontologists excavated the sedimentary layers in the caves of Dragon Bone Hill. These deposits yielded hominid teeth, skull caps and mandibles, as well as stone artifacts and evidence suggesting the use of fire. At this site, the scientists discovered the so-called Peking man (Sinanthropus pekinensis), a fossil hominid dating back at least 600,000 years but now relegated to the long Homo erectus phase of human evolution. While excavating the rock strata of these caves for the Cenozoic Research Laboratory, Teilhard first worked under the direction of Davidson Black and then Franz Weidenrich; this unique geological location still remains one of the most significant fossil hominid sites in the world. Teilhard became world-known as a result of his popu- larization of the Sinanthropus discovery. As a skilled stratigrapher, he himself made major contributions to the geological study of this site. Furthermore, Teilhard's long stay in China offered him the luxury of time to think and to write, as well as to continue his scientific research.

Like the biogeologist Darwin, the geopaleontologist Teilhard was able to conceive of life forms evolving over seemingly endless periods of time, as well as to reflect on the emergence of the human animal from those remote fossil apes that once inhabited Africa. Both explored the earth with his ever-present geologist's hammer and scientific field notebook. As such, it is intriguing to imagine Darwin investigating the caves of Dragon Bone Hill, and Teilhard exploring the islands of the Galapagos Archipelago. And also like Darwin, Teilhard's early interests shifted more and more from geology, through paleontology, to anthropology.

\section{AN EVOLUTIONARY SYNTHESIS}

Unlike the outmoded views of Archbishop James Ussher, William Paley, and Philip Gosse, the mature Teilhard had always rejected a strict and literal interpretation of Genesis in favor of an evolutionary perspective. However, there is an arc of interpretations of evolution in the serious literature: from materialism, through vitalism and spiritualism, to mysticism. Bringing his own scientific knowledge and religious commitments together, the Jesuit geopaleontologist now began writing a synthesis of facts and beliefs, with the aim of demonstrating the special place held by our species in this dynamic universe. He was determined to show that our species is, in fact, unique in the world. After two years, writing several paragraphs each month, Teilhard completed his major work, The Phenomenon of Man (1938-1940, with a postscript and appendix added later in 1948). It focuses on the unique appearance of our single species within organic evolution on this planet. For other religionists, his evolutionary synthesis was a threat to traditional theology and, consequently, it was denied publication in 1944. In retrospect, however, it is with bitter irony that this book was so controversial because it had offered an earth-bound and human-centered interpretation of evolution. It is essentially an ultra-anthropology grounded in a phenomenology of evolution in terms of emerging consciousness, as well as a spiritual worldview advocating cosmic panentheism and planetary humanism.

In The Phenomenon of Man, an enthusiastic Teilhard writes: "Is evolution a theory, a system or a hypothesis? It is much more: it is a general condition to which all theories, all hypotheses, all systems must bow and which they must satisfy henceforth if they are to be thinkable and true. Evolution is a light illuminating all facts, a curve that all lines must follow... The consciousness of each of us is evolution looking at itself and reflecting upon itself... Man is not the center of the universe as once we thought in our simplicity, but something much more wonderful - the arrow pointing the way to the final unification of the world in terms of life. Man alone con- 


\section{Teilhard de Chardin}

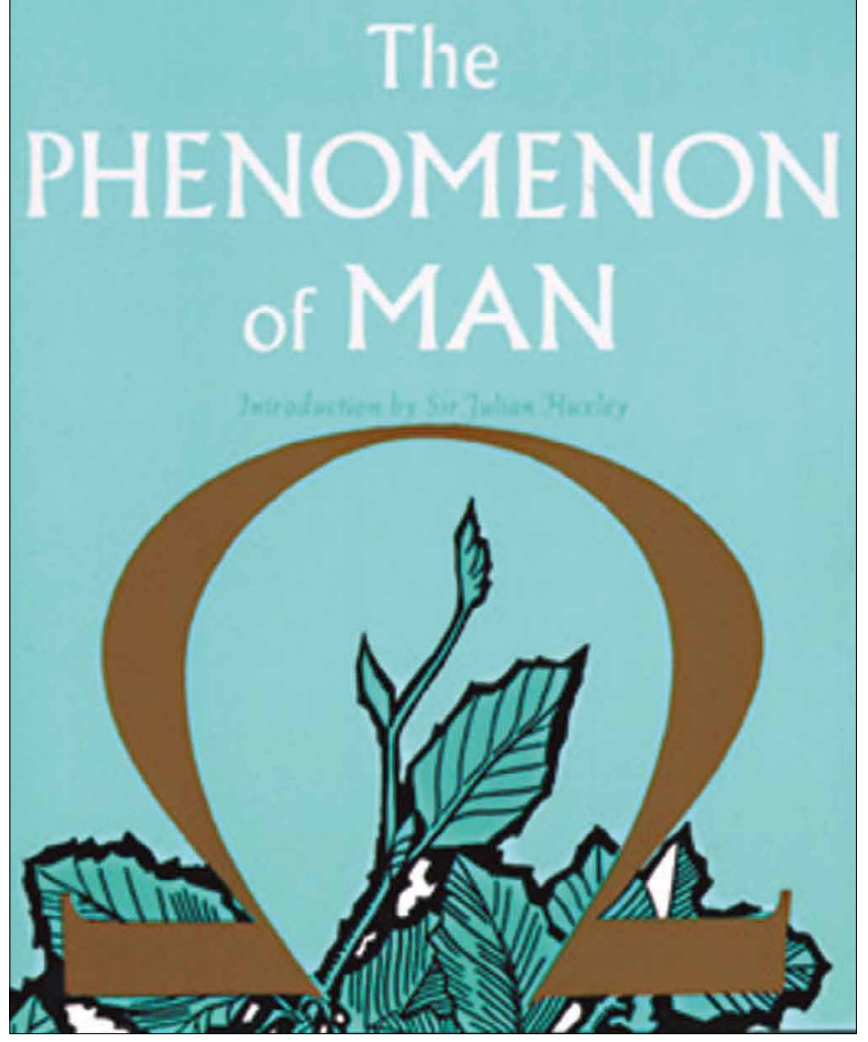

Fig. 6. The Phenomenon of Man (book cover).

stitutes the last-born, the freshest, the most complicated, the most subtle of all the successive layers of life... The universe has always been in motion and at this moment continues to be in motion. But will it still be in motion tomorrow?... What makes the world in which we live specifically modern is our discovery in it and around it of evolution... Thus in all probability, between our modern earth and the ultimate earth, there stretches an immense period, characterized not by a slowingdown but a speeding up and by the definitive florescence of the forces of evolution along the line of the human shoot" (Teilhard 2008, 219, 221, 224, 229, 277). No doubt, the evolutionary stance of this work was sufficient enough to warrant its being condemned by the dogmatic religionists of that time. Nevertheless, the fact of evolution was an overwhelming paradigm shift that had required a profound reinterpretation of time, change, and life itself (including new conceptions of reality, experience, and human values). Of course, religions and theologies have also evolved throughout human history. Many readers did find Teilhard's spiritual vision full of hope and inspiration; it presented a conceptual framework of love and action for building a new earth that would value both the individual person (as had been emphasized by Friedrich Nietzsche) and a collective humankind (as had been emphasized by Karl Marx). Unlike many researches in the special sciences, Teilhard was deeply concerned with the ongoing survival and fulfillment of our species in terms of the shape of things to come on this planet.

Teilhard had chosen those concepts that would allow him to interpret evolution in such a way as to save his fundamental religious and theological beliefs in God, free will, immortality, and a divine destiny in the conventional Judeo-Christian-Islamic tradition. Consequently, some readers were pleased by and excited over Teilhard's engaging and illuminating interpretation of creative vitalism and mystical evolution. Clearly, his spiritualism offered a worldview that is far removed from the scientific naturalism as mechanistic materialism of Charles Darwin, Richard Dawkins, Daniel C. Dennett, and Stephen Wolfram, including the philosophical naturalism of critical thinkers from John Dewey to Marvin Farber (among other evolutionists in science and philosophy).

Teilhard's impressive contributions to Chinese geology, paleontology, and archaeology may be seen in the 11 volumes of his scientific writings (Schmitz-Mormann 1971). They include his own extensive work related to the Sinanthropus pekinensis discoveries from the Dragon Bone Hill caves at Zhoukoudian near Peking, China. Together, his scientific and philosophical writings, along with his many letters and essays, fill at least 27 books.

Briefly, for Teilhard, the Mosaic cosmogony is replaced by emergent evolution within which the biblical Adam and Eve become replaced by fossil apelike forms in the remote past! Furthermore, one is reminded of Ludwig Feuerbach's call for a philosophical anthropology that takes seriously the ongoing findings of the special sciences within a humanistic framework.

\section{ENVISIONING THE OMEGA POINT}

Teilhard argues that the universe is a cosmogenesis. Essentially for him, the unity of this cosmos is grounded not in matter or energy, but rather in spirit (the within-of-things or radial energy or love energy); thereby, he gave priority to dynamic spirit rather than to atomic matter (the without-of-things or tangential energy). In short, for the Jesuit scientist, ultimate reality is grounded in quantum mysticism. Reminiscent of Lamarck and Bergson, Teilhard was a vitalist who saw the spiritualizing and personalizing universe as a product of an inner driving force manifesting itself from material atoms, through life forms, to reflective persons. He saw meaning and purpose in this sweeping epic of cosmic evolution, particularly in the emergence of humankind. However, Teilhard's alleged cosmology is actually a planetology, since the scientist-priest focused his attention on the earth without any serious consideration of the billions of galaxies, each with billions of stars, strewn throughout sidereal reality.

Of primary significance, Teilhard argued that the assumed order in nature reveals a pre-established plan as a result of a divine designer, who is the transcendent God of Christianity as the Center of creation or Person of persons; actuality, autonomy, 


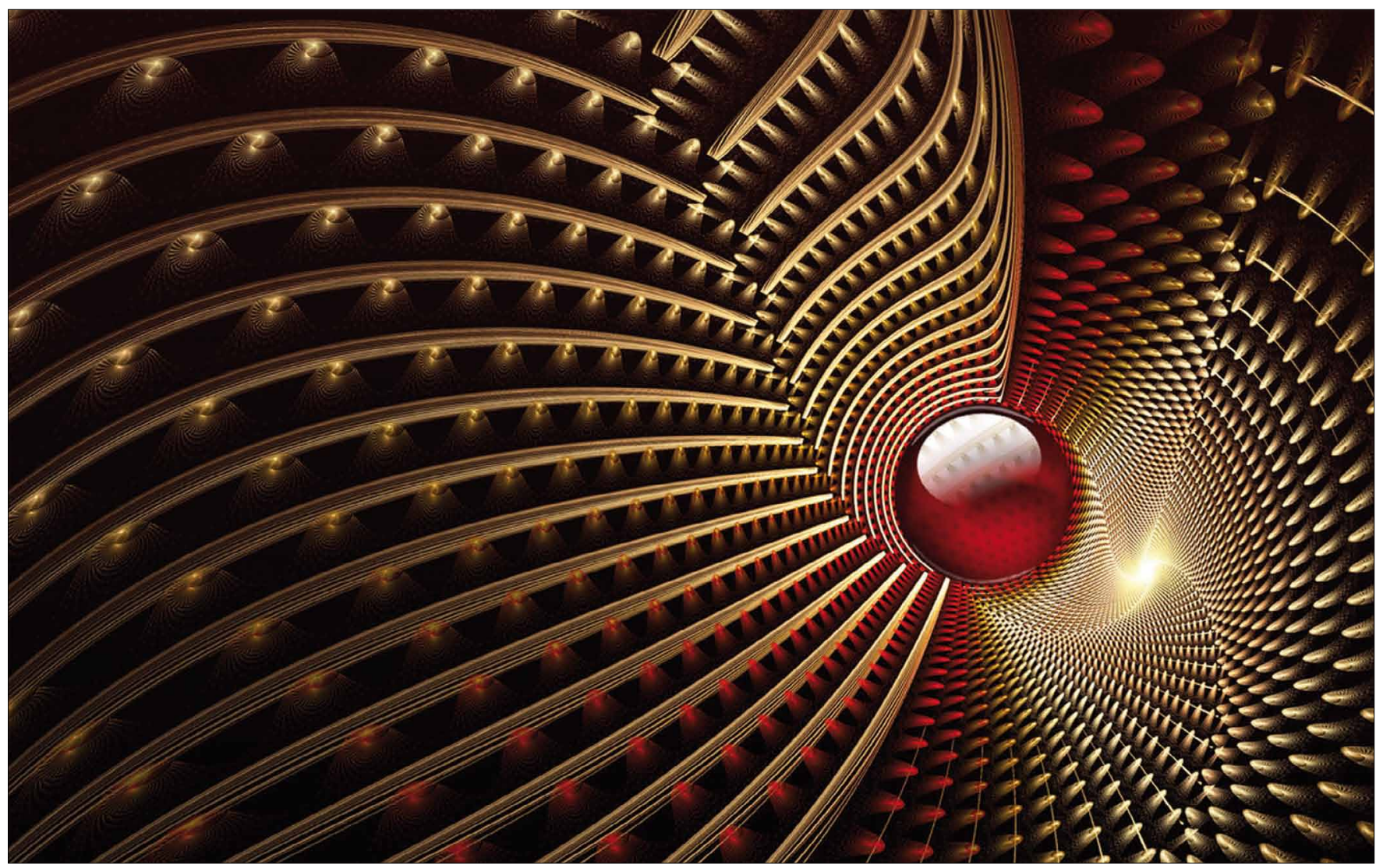

Fig. 7. Convergence (illustration).

irreversibility, and transcendence are the essential aspects of God-Omega. The evolving direction in nature is a result of the process law of complexity-consciousness; the Aristotelian idea that nature manifests a static hierarchy had been transformed into an evolutionary interpretation of this universe by Herbert Spencer (among other serious thinkers). For Teilhard, in terms of size-complexity, the results of evolution range from immense stars to the human brain. But, he was deeply concerned not with the infinitely great or the infinitely small, but rather with the infinitely complex that would emerge in the distant future as a spiritual synthesis. As such, his evolutionary worldview is grounded in teleology and convergence.

For Teilhard, this cosmic law manifests itself from the inorganic atoms through organic species to the human animal itself. Or, this teleological process has resulted in the appearance of Matter, then Life, and finally Thought. Evolution is the result of "directed chance" taking place on the finite sphericity of planet earth. For Teilhard, God-guided evolution is converging and involuting around this globe: first through geogenesis, then biogenesis, and now through noogenesis. As human evolution continues to spiral forward and upward (as he saw it), a layer of collective minds as spirits will continue to encircle our earth, forming a planetary consciousness. The result of evolution was a geosphere surrounded by a biosphere, and now an emerging noosphere or layer of human thought and its products is enveloping the biosphere and the geosphere. Essentially, Teilhard held that noogenesis is a Christogenesis that will end in the for- mation of a theosphere. For the Jesuit mystic, the Divine Center of this noogenesis is the God-Christ of spiritual reality.

The idea of a forming noosphere was also explored in the writings of the Russian philosopher Vladimir Vernadsky (1863-1945), while Herbert Spencer and the American anthropologists Alfred Kroeber (1876-1960) and Leslie A. White (1900-1975) spoke of the 'superorganic' or human culture as an outgrowth of an organic evolution preceded by an inorganic development.

Throughout evolution, there have been critical thresholds crossed which account for the uniqueness of both life over matter and the human being as a person with an immortal soul over all other life forms. Unlike Thomas Huxley, Ernst Haeckel, and Charles Darwin, Teilhard claimed that the human being is separated from the great apes (orangutan, gorilla, chimpanzee, and bonobo). Obviously, for the Jesuit priest, the process of evolution has not been a continuum: from time to time, evolution has crossed critical thresholds resulting in the emergence of qualitatively different manifestations of matter as ever-greater complexity and ever-more consciousness or concentrated spirit. For Teilhard, the evolution of matter is quintessentially the evolution of spirit. Unlike all other forms of life, he believed that the human being has an immortal soul. For Teilhard, the ongoing spiritual evolution of our species is moving toward an Omega Point as the divine destiny of human evolution on this planet. This future Omega Point will be the ultimate-outcome or final-synthesis or end-goal of human evolution on the earth. 


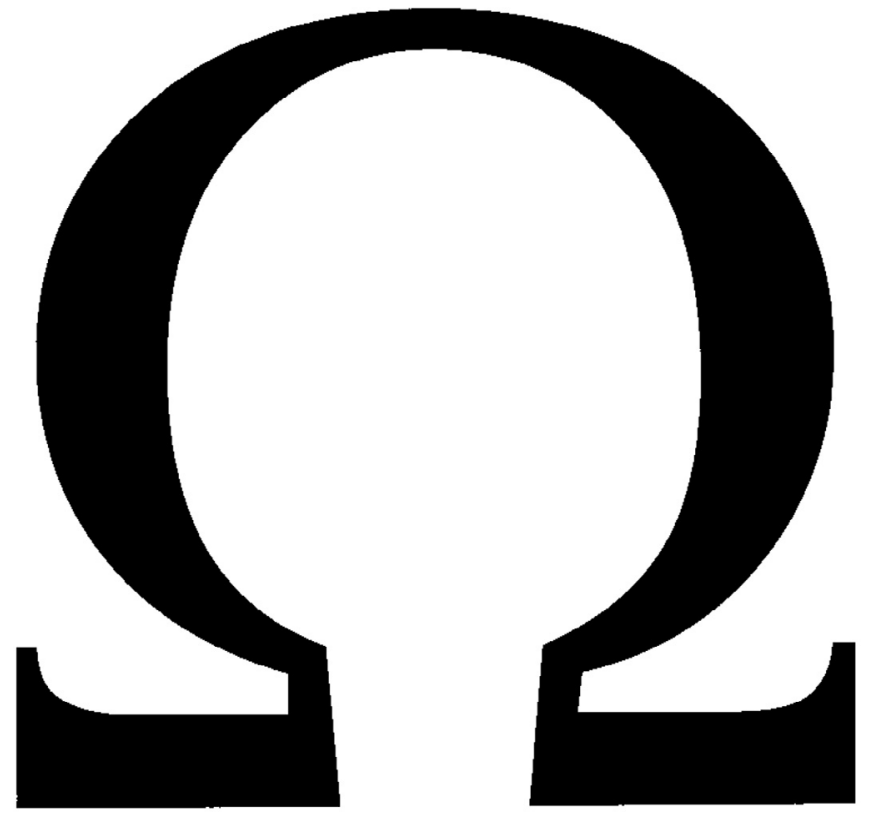

Fig. 8. Omega Point (symbol).

His theism maintains that God-Omega is one, personal, actual, and transcendent. In the last analysis, Teilhard's incredible vision of the end-goal for human evolution on the earth held that God-Omega and the Omega Point will become united in a mystical synthesis of spiritual unity.

Grounded in agapology and centrology, Teilhard's interpretation of evolution claims that the human layer of consciousness now engulfing our earth is becoming a collective brain and heart that will, in the future as a single mind of persons, detach itself from this planet and, transcending space and time, be immersed in God-Omega; the end-goal of evolution is a final creative synthesis of a united humankind with the universal God-Omega. Thus, his panentheism became (at least in part) a mystical pantheism. However, Teilhard did not take seriously the possibility of exobiology and exoevolution, e.g., the possibility that Omega Point events have happened, are happening, or will happen elsewhere in this universe. As a Jesuit priest, he wanted to maintain the uniqueness of the human being on this planet. Similar views of God and the World may be found in the writings of Samuel Alexander, Alfred North Whitehead, and Charles Hartshorne (among other philosophers). Most recently, Frank J. Tipler has extended Teilhard's planetary vision to that of a truly cosmic one, in which God-Omega will emerge through technological emulations countless billions of years from now just before the end of this universe!

\section{CONSEQUENCES: POSITIVE \& NEGATIVE}

In general, the Judeo-Christian-Islamic tradition had not accepted the mutability of species (especially in view of the then-believed sudden and recent divine creation of the human being). In particular, the Roman Catholic Church did not accept organic evolution as a brute fact of natural history.
Consequently, it is not surprising that The Phenomenon of Man was denied publication by his superiors. Nevertheless, Teilhard obeyed his ecclesiastical authorities. He then wrote Man's Place in Nature: The Human Zoological Group (19491950) as a more scientific statement of his interpretation of evolution (focusing on our species) in terms of teleology and spiritualism. With controlled enthusiasm, he writes: "Man is, in appearance, a 'species,' no more than a twig, an offshoot from the branch of the primates - but one that we find to be endowed with absolutely prodigious biological properties.... Without the earth could there be man?" (Teilhard 1966, 15, 25). Unfortunately, the publication of this book was also denied, along with his request to teach in Paris. Even so, reminiscent of the silencing of Galileo Galilei, one can imagine Teilhard as an evolutionist saying to himself: "Eppur si muove?" On 12 August 1950, Pope Pius XII issued the Encyclical Letter Humani generis in which he gave priority to a Thomistic interpretation of Divine Revelation as contained in the Holy Scriptures over the growing empirical evidence of the special sciences concerning earth history and life forms upon it. In this document, he warned that opinions on the theory of evolution may be erroneous, i.e., fictitious or conjectural. Briefly, for him, evolution was held to be merely a questionable hypothesis and possibly even sterile speculation or only false science. Obviously, this papal warning from the Vatican was (at least in part) a direct result of Teilhard's unsuccessful request for the publication of his slightly revised version of The Phenomenon of Man in 1948.

Because of his unendurable anguish in France, Teilhard left Paris and returned to New York City, now being more or less an outcast from the country of his birth. He had left all his unpublished manuscripts with Jeanne Mortier, his secretary in Paris; only after his death were Teilhard's three books and religious writings collected and made available to the public, because now the restriction on their publication was no longer binding. Becoming an associate at the Wenner-Gren Foundation (formerly the Viking Fund), he spent the last five years of his life dedicated to human evolution and his everpresent teleological view of this universe. Teilhard always claimed that Darwinism is necessary, but not sufficient, to account for the movement of forms of life from bacteria to our species; Darwin was a mechanistic materialist, but Teilhard remained a mystical spiritualist. Moreover, unlike the philosopher Friedrich Nietzsche (1844-1900), who emphasized the superior creative individual, Teilhard valued a collectively active humankind. And, the eternal recurrence of the same (as Nietzsche taught it) is replaced by the scientist-priest with a merely one-time framework for cosmic evolution.

Interestingly enough, the secular humanist Sir Julian Huxley appreciated Teilhard's religious humanism, which clearly did see our species, life, and earth history within the dynamic perspective of a synthesis grounded in planetary evolution. However, Huxley could not accept Teilhard's overall commitment to spiritual transcendence rather than to seeing evolution as a strictly naturalistic process.

During his final years in New York City, Teilhard twice took 
the opportunity to visit fossil hominid sites in South Africa. New empirical evidence was giving more and more scientific credence to an interpretation of the earlier stages of human evolution. Unfortunately, at the end of his distinguished life, Teilhard was somewhat removed from significant new developments in evolutionary science, e.g., the 1953 discovery of a working model for the DNA molecule, which became a key aspect for understanding and appreciating the emergence of new life forms through random genetic variation and necessary natural selection within dynamic populations. For the evolutionist as materialist, organic creativity is grounded in chance and contingency. If he were alive today, then what would Teilhard think about the far-reaching applications of nanotechnology and bioengineering for further human evolution? (Similarly, one would love to know what were the aged Darwin's final thoughts on religion and theology as he reflected upon evolution during his daily strolls down the Sandwalk behind Down house.) Furthermore, what would Teilhard think of the scientific possibility of creating transhumans in the near future, and posthumans emerging in the remote future?

Even though he espoused a geological perspective and saw our species continuing to evolve for millions of years, Teilhard still held that humankind would never leave this planet! He offers a myopic vision of the future, in which our species is spiritually nailed to the earth and absolutely alone in this universe. Of course, this suffocating centrology was necessary in order for him to believe in the formation of an Omega Point at the end of human evolution in terms of spiritual involution and divine convergence on this planet.

From time to time, especially during the last years of his life, Teilhard felt deeply the pain of being rejected by both his superiors in the Jesuit order and the pope of the Roman Catholic Church. He suffered moments of doubt, fits of weeping, and periods of depression; sometimes, his torments almost overwhelmed him and he was on the verge of utter despair. Apparently, Teilhard never took seriously the option of leaving both the Jesuit Society and the priesthood.

No doubt, one finds it very disconcerting that Teilhard wept over his pathetic ordeal within the Jesuit order. And, one may find it somewhat unsettling that, as a Jesuit priest, he spent considerable time traveling and communicating with several beautiful women whose friendship he encouraged, even though they could never find a lasting intimate relationship with this spiritual and mystical man who gave preference to a transcendent God over those individuals who loved him in this world. Of course, Teilhard was a man of flesh and blood who, struggling with his own beliefs and commitments within an intellectually hostile environment, no doubt needed that human companionship provided by those women who found him attractive in every way.

On Easter Sunday, 10 April 1955, Teilhard died of a sudden stroke in New York City; outside the apartment, spring was flooding the early evening with sunshine. Several weeks later, he was buried at St. Andrew-on-Hudson, in the cemetery of the Jesuit novitiate for the New York Province (his earthly re-

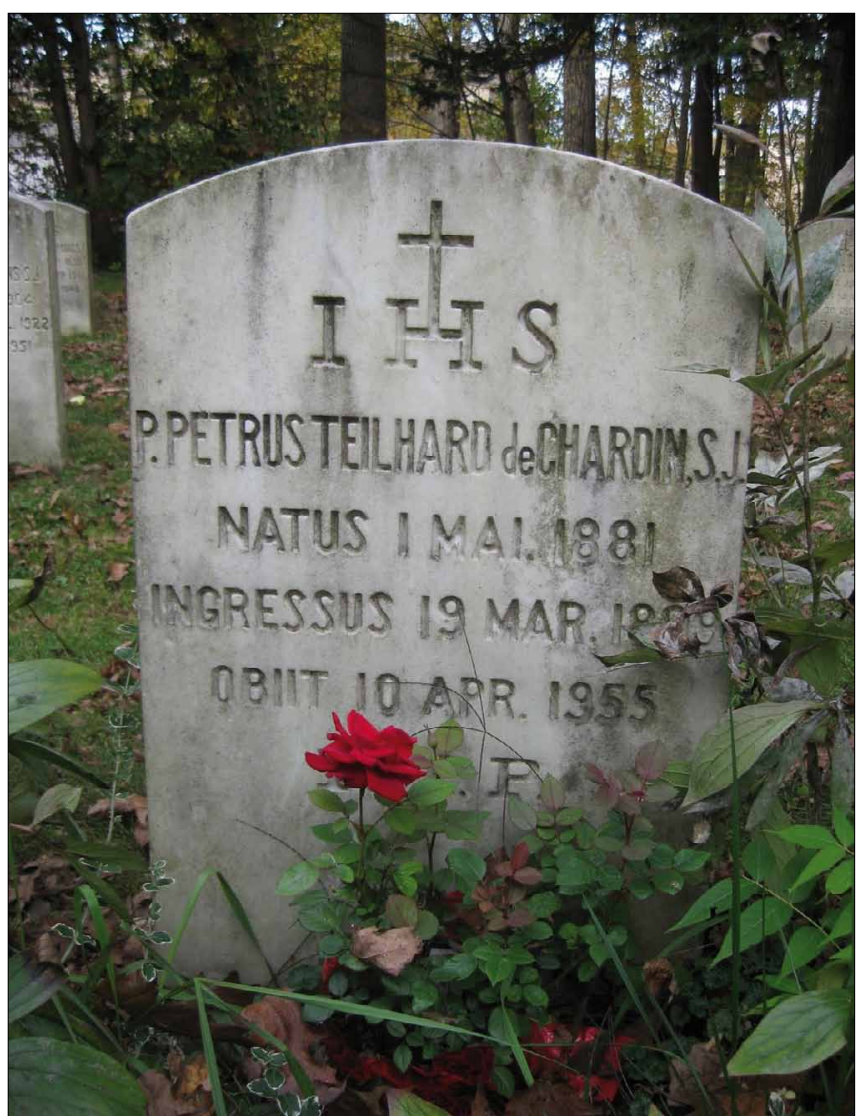

Fig. 9. Grave Site.

mains far removed from France). By the fall of that year, the first edition of The Phenomenon of Man was published in its author's native language. However, in 1962, a Monitum decree issued by the Holy Office on Teilhard's works went as far as to warn bishops and heads of seminaries of the doctrinal errors said to be inherent in the Jesuit scientist's philosophical interpretation of humankind within evolving nature.

\section{REMEMBERING TEILHARD: SOME FINAL THOUGHTS}

Teilhard's evolutionary optimism seems to have overlooked the extensive role that extinction plays throughout organic evolution (not to mention excessive evil); those mass extinctions, which caused all the trilobites, ammonites, and dinosaurs to vanish forever, should tarnish the unbridled optimism of any rigorous evolutionist. Furthermore, Teilhard's vision does represent a form of the anthropic principle; the evolving universe is the way that it is in order for our species to emerge in cosmic evolution. However, the pervasive extinctions throughout organic evolution, and the fact that even archaebacteria would not have existed several billion years ago if the universe was not the way that it was then, will not convince many serious thinkers that it was inevitable for our species to appear in this universe. The anthropic principle represents anthropocentrism at its extreme. 


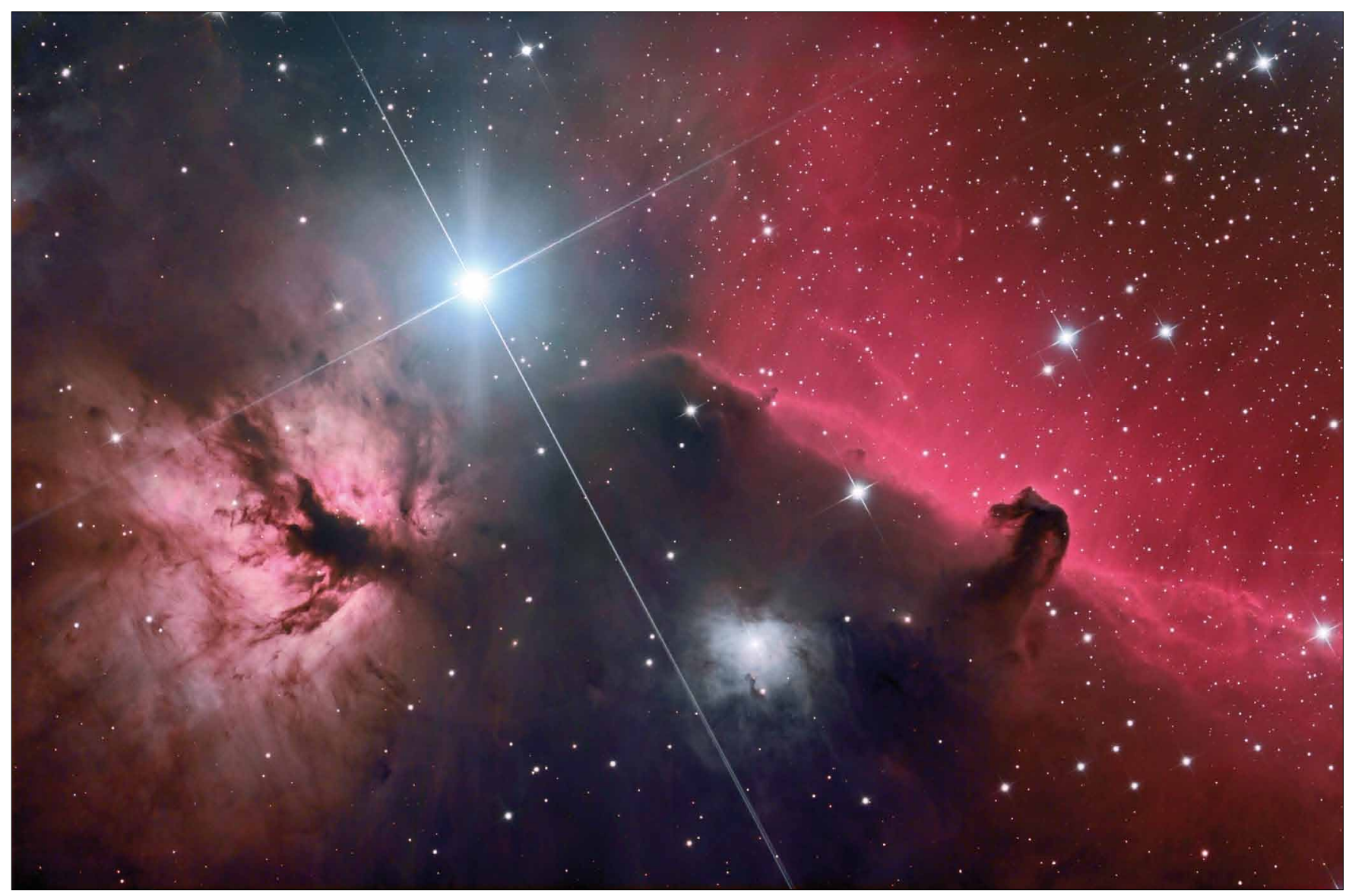

Fig. 10. Cosmic Perspective.

Once again, claiming that everything that rises must converge, Teilhard grounds his philosophy of evolution in mysticism. The movement of Matter, then Life, and finally Thought is both forward and upward to a mystical union with GodOmega (the beginning and end of cosmic evolution). But most scientists will not follow Teilhard's directional interpretation of this evolving universe. For the Jesuit priest, cosmic chaos and probability are giving way to human teleology and certainty. Teilhard's severest critic was the British zoologist Sir Peter Medawar, a Nobel laureate who wrote a scathing review of The Phenomenon of Man; he found Teilhard's evolutionism to be not only preposterous, but also an attempt on Teilhard's part to deceive himself. However, the prominent geneticist Theodosius Dobzhansky praised Teilhard's vision of evolution and was greatly influenced by it.

Adding insult to injury, as did the late paleoanthropologist Louis S. B. Leakey, the Harvard paleontologist Steven Jay Gould maintained that Teilhard had been directly involved with the infamous Piltdown man hoax. One may suspect that Leakey was too eager to discredit the outstanding scientific accomplishments of Teilhard by implicating him as a direct conspirator in the unfortunate Piltdown man fraud after the beginning of the last century. And, one may argue further that it is both surprising and disappointing that Gould had besmirched the international reputation of an exemplary natural scientist and virtuous human being by suggesting that Teilhard had been a conspirator in the Piltdown man hoax without a single thread of incontestable evidence to support such a damaging claim. Invoking "innocent until proven guilty" and in light of his reputation as a very distinguished natural scientist and most commendable human being, it seems only fair to assume that Teilhard was innocent of any direct wrongdoing in this singularly outrageous perpetration of a false discovery in human evolution research. In fact, during his later years, Teilhard himself received several prestigious awards for his extraordinary contributions to geopaleontology.

No doubt, Teilhard himself would be alarmed at the present return of biblical fundamentalism and so-called scientific creationism. Yet, his own interpretation of cosmic reality represents a form of intelligent design. Nevertheless, the optimistic Jesuit priest was committed to science and evolution, despite his metaphysical speculations and mystical orientation. He was, in some respects, a freethinker as religious humanist; a visionary and futurist who foresaw the collective consciousness of our global species increasing in terms of information and technology. It is to Teilhard's lasting credit that he introduced into modern theology the fact of organic evolution at a time when this scientific theory of evolving nature was rejected by many who saw it as a threat to their entrenched beliefs and traditional values. Unfortunately, in trying to rec- 
oncile the irreconcilable (as I see it), Teilhard pleased no intellectual community. Even today, although wisely not opposed to the fact of evolution, the Roman Catholic Church has as yet not offered a comprehensive and detailed explanation for both the origin of life and the appearance of humankind in order to replace a neo-Darwinian interpretation of planetary history or a neo-Teilhardian vision of this universe.

Unlike the iconoclastic Renaissance philosopher Giordano Bruno (1548-1600), whose glorious cosmology argued for this universe being one of eternal time and infinite space and endless change, as well as for the existence of intelligent life forms elsewhere in this cosmos and the existence of countless island universes, Teilhard focused exclusively on the earth and gave special attention to our own species. Briefly, the Jesuit-scientist has given us a phenomenology of this planet, i.e., an analysis of those essential structures of evolution throughout earth history in terms of emerging consciousness and spiritual intentionality. In this respect, he was not in step with those modern thinkers who offer a truly cosmic perspective in which the existence of humankind is merely a fleeting event in this material universe. Instead, Teilhard's mysticism reminds one of the cosmic visions of Joseph Ernest Renan (1823-1892) and Miguel de Unamuno (1864-1936).

Surprisingly, on 23 October 1996, Pope John Paul II issued a statement to the Pontifical Academy of Sciences in which he endorsed evolution as being "more than just a theory" and thereby biblical fundamentalism and so-called scientific creationism were dealt yet another blow to their vacuous claims about the origin of this universe and the appearance of life forms on planet earth. With bitter irony, it was the silenced Teilhard who had committed himself to the fact of evolution, as well as to the indisputable powers of science, reason, and open inquiry. Both spiritualists and materialists can admire Teilhard's own courageous commitment to evolution. Furthermore, he offered a religious humanism that recognized the value of both an individual and our collective species. Actually, Teilhard had even anticipated our age of the Internet; he envisioned an evolving global mind in terms of love, spirit, information, and technology. His extraordinary imagination had glimpsed a planetary unity of collective consciousness that foreshadows the emergence of a global super-organism. Such insights still continue to inspire enlightened and imaginative intellects.

A rigorous evolutionist sees reality grounded in energy (not spirit) and manifesting no evidence of a divine plan unfolding throughout this dynamic universe; our species is linked to material nature, and it is species-centric to claim that a mystical destiny awaits humankind at the end of cosmic time. Because of his pre-DNA orientation and pre-space-age perspective, Teilhard had not envisioned the scientific enhancement of our own species through the application of nanotechnology and bioengineering. Consequently, the Jesuit priest did not foresee the possible coming of transhumans or the future emergence of posthumans. Instead, his vision emphasized the ongoing convergence and involution of human consciousness on the earth; it gave no serious attention to the probability that our species would leave this planet, surviving and evolving elsewhere in this dynamic universe.

\section{CONCLUSION}

In modern astronomy and cosmology, scientists have discovered many aspects of this universe that were unknown to Teilhard during his lifetime. Consequently, one wonders what he would think of these new objects and new ideas that are grounded in quantum mechanics and relativity physics: quarks, quasars, pulsars, black holes, superstrings, Higgs bosons, dark matter, dark energy, negative time, eleven dimensions, parallel universes, and an eternal multiverse. No doubt, Teilhard would have incorporated all these entries into his own spiritual and mystical worldview. Furthermore, he would certainly be delighted with the ongoing quest for a theory of everything. However, Teilhard would probably be reluctant to take seriously the existence of a universe with no absolute beginning and no absolute end. Furthermore, he would probably be reticent to accept the speculation that future-created sentient super-intelligent computers could become capable of both out-thinking and out-performing human beings.

From ancient philosophers to modern scientists, both cosmologists and astrobiologists have speculated on the possibility of life forms (including intelligent beings) existing on other planets elsewhere in this material universe. Today, scientists acknowledge that there are billions of galaxies, each with billions of stars and, no doubt, billions of planets. This immensity is beyond human comprehension; the vastness of this universe alone should discredit any anthropocentric worldview. It must be remembered that Teilhard's assumed cosmology is, in fact, merely a planetology that focuses essentially on the recent emergence of our species in earth history. As such, the scientist-priest never took seriously the existence of life and thought elsewhere in material reality. Of course, this does not discredit his deep concern for the ongoing survival and future fulfillment of evolving humankind on this planet.

In modern paleoanthropology, one may speak of the Anthropocene epoch as the present time of human evolution. In fact, fossil hominid species have been unearthed in Africa that had been unknown to Teilhard during his lifetime, e.g., ramidus, anamensis, afarensis, platyops, africanus, sediba, robustus, boisei, and habilis. New paleoanthropological sites in South Africa have yielded fossil evidence that substantiates hominid diversity several million years ago. These bipedal ancestors lived in small isolated groups and evolved as they adapted to sporadic changes in the environment. In at least one species, a dynamic genes-habitats syndrome (with ongoing cultural innovations) resulted in the emergence of cognitive skills, social cooperation, including shared intentionality and empathy, and symbolic language as articulate speech; all these aspects helped to evolve Homo habilis and the following Homo erectus into our Homo sapiens of today. 


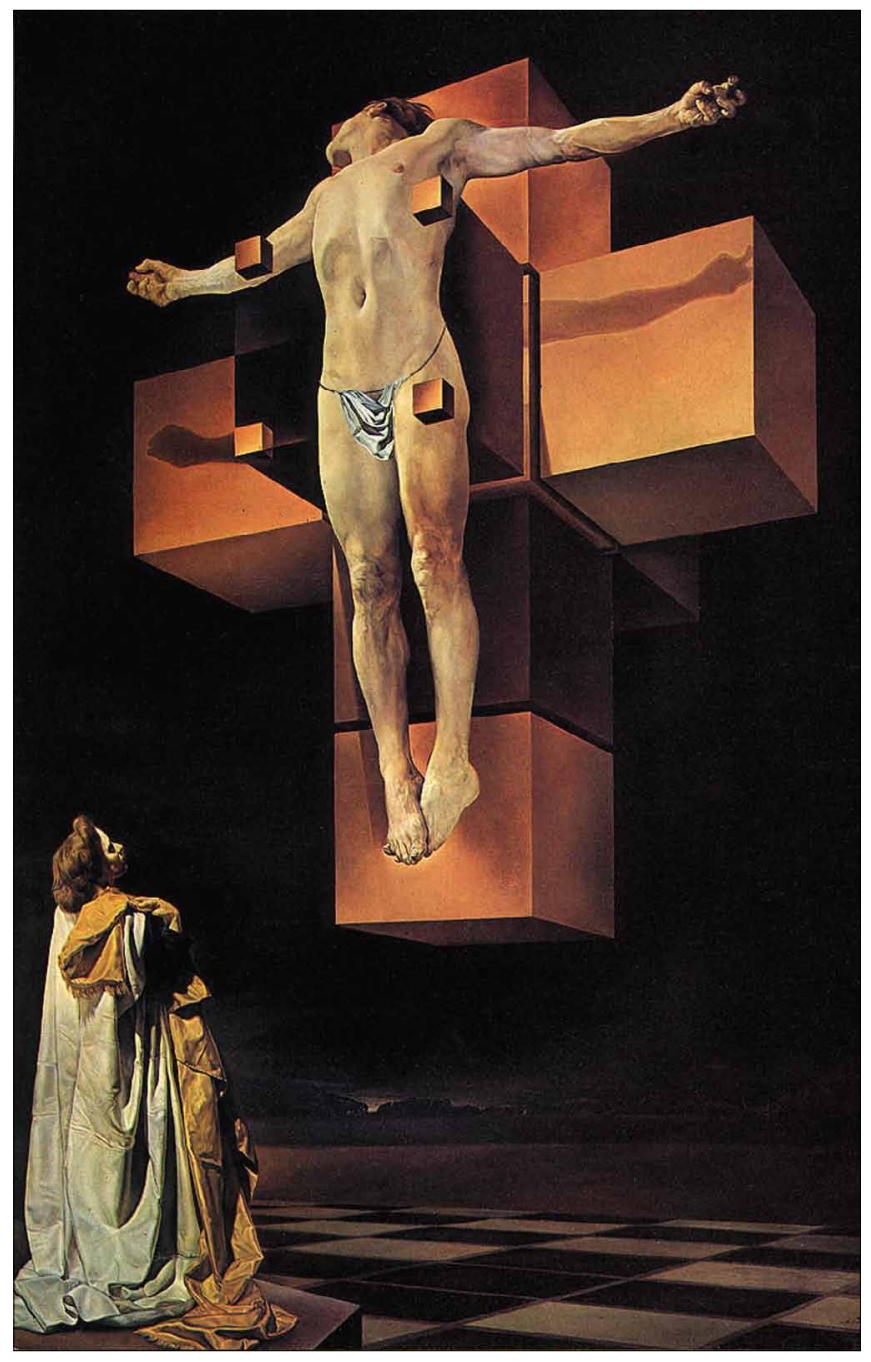

Fig. 11. Dali's Crucifixtion/Corpus Hypercubus (1954).

(Raymond A. Dart's controversial "killer ape" hypothesis remains an intriguing interpretation of early hominid social behavior). In his writings, Teilhard emphasized the converging unity of our single subspecies.

Surely, in the future, paleoanthropologitsts will continue to discover other species representing the hominid adaptive radiation during the long Villafranchian time of the Pleistocene epoch. Nevertheless, if he were with us today, Teilhard would concentrate on the successful Homo habilis, Homo erectus, and Homo sapiens sequence of hominid evolution over the past 2 million years.

One wonders what Teilhard would think about the massive bones of the huge dinosaur Argentinosaurus huinculensis unearthed in 1987 from a Cretaceous fossil site in Patagonia, South America. It is likely that astonishing fossil hominoid specimens are yet to be discovered and interpreted by geologists and paleontologists, e.g., the near-complete fossil remains of the enormous pongid Gigantopithecus blacki and the bipedal hominid Homo habilis.

Not until after Teilhard's death in 1955 did anthropologists

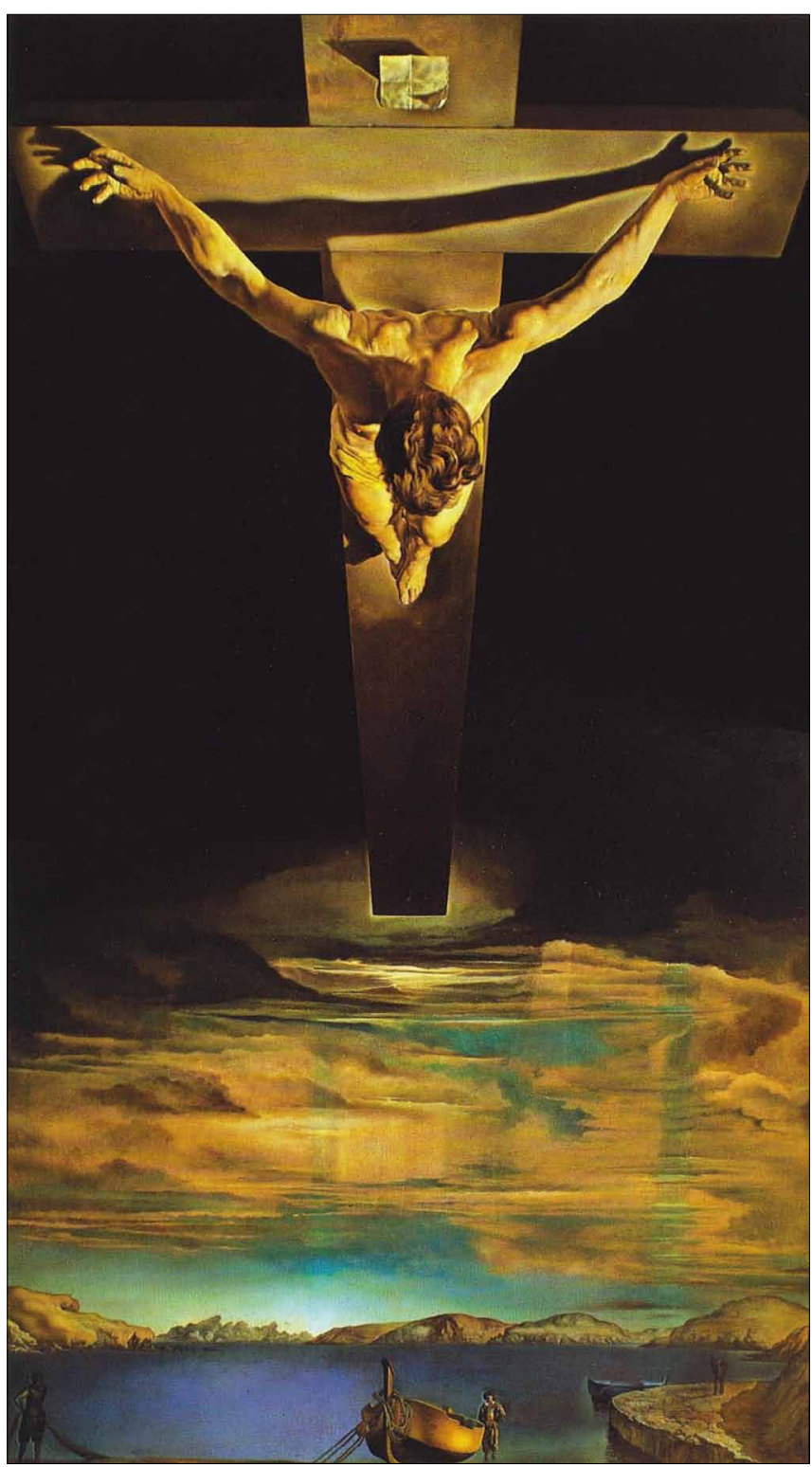

Fig. 12. Dali's Christ of Saint John of the Cross (1951).

begin their short-range, long-term observations of wild apes in their natural habitats. Over the years, these studies have revealed the fact that the four pongids are remarkable similar to our own species. Thomas Huxley, Ernst Haeckel, and Charles Darwin himself would be surprised at just how close the great apes are to the human being in terms of biology, psychology, and behavior. One may conclude that our own species differs merely in degree, rather than in kind, from the orangutan, gorilla, chimpanzee, and bonobo. The scientific evidence challenges Teilhard's claim that Homo sapiens is a unique species that is separated from all the other life forms on this planet. In fact, because of their undeniable similarities, paleoanthropologist Richard E.F. Leakey has even suggested that the four pongids and the human animal should be placed in the same taxonomic genus.

It was the bold Teilhard who said: "We must dare all things!" 
Certainly, he would be readily open to accepting all our modern advances in both science and technology, including the awesome possibilities of nanotechnology and bioengineering, but within ethical guidelines. As such, one may argue that his vision of the future had even anticipated, to some degree, the scientific creation of a transhuman being.

Six decades after his death, Teilhard remains both a controversial and provocative thinker for our modern age. As I see it, despite his earth-bound and human-centered orientation, he has made two lasting contributions to an emerging ultra-anthropology: his boldly embracing the scientific fact of organic evolution in general, and his astutely recognizing the global convergence of our species in particular. Clearly, Teilhard's evolutionary vision is in sharp contrast to Aquinas's static and outmoded worldview. Consequently, Teilhard's dynamic theology is a radical departure from the traditional theology of Roman Catholicism. By incorporating both past-time and future-time into his philosophical synthesis, Teilhard developed a planetary vision that is in step with the continuing advances in the special sciences and natural philosophy.

Always optimistic, Teilhard never took seriously the possible extinction of our own species due to an insidious global plague or a devastating meteor strike. No doubt, his ever-present mysticism allowed him to overcome the possibility of human extinction. Even so, the wisdom of evolution maintains that, in the ongoing struggle to adapt to pervasive change in nature, no species is exempt from the treat of extinction.

One may envision a forthcoming neo-Enlightenment. With both the will to evolve and dynamic integrity, resulting in emerging teleology through nanotechnology and bioengineering, I refer to our distant enhanced species as Homo futurensis, to be followed in deep time by a posthuman life form as the cosmic overbeing that will inhabit the deep space of this expanding universe.

Teilhard had a penetrating awareness of ultimate reality (as he intuited it). He did not offer a metaphysics of universal being, but rather a metaphysics of cosmic becoming, with an intense and deliberate focus on our own species. He was a unique individual of intelligence, integrity, and sensitivity. As a Jesuit priest, his fascinating but tragic life was a scientific but solitary journey to a mystical vision of cosmic becoming. He envisioned an ultra-anthropology that would be a comprehensive and integrated interpretation of and appreciated for the place of our human species within the awesome vastness of this dynamic and evolving universe. As such, Teilhard experienced both the agony and ecstasy of time and change while meditating on the steppes of Mongolia, serving on the blood-stained battlefield of a war-torn humanity, researching among those rocks and fossils that represent a remote geological past, and meditating on the distant destiny of humankind as he reflected on evolution in the deepest recesses of his soul.

In the last analysis, one may argue that Pierre Teilhard de Chardin himself best represents that individual who had been sincerely dedication to grasping the significance of evolving humankind within this dynamic universe.

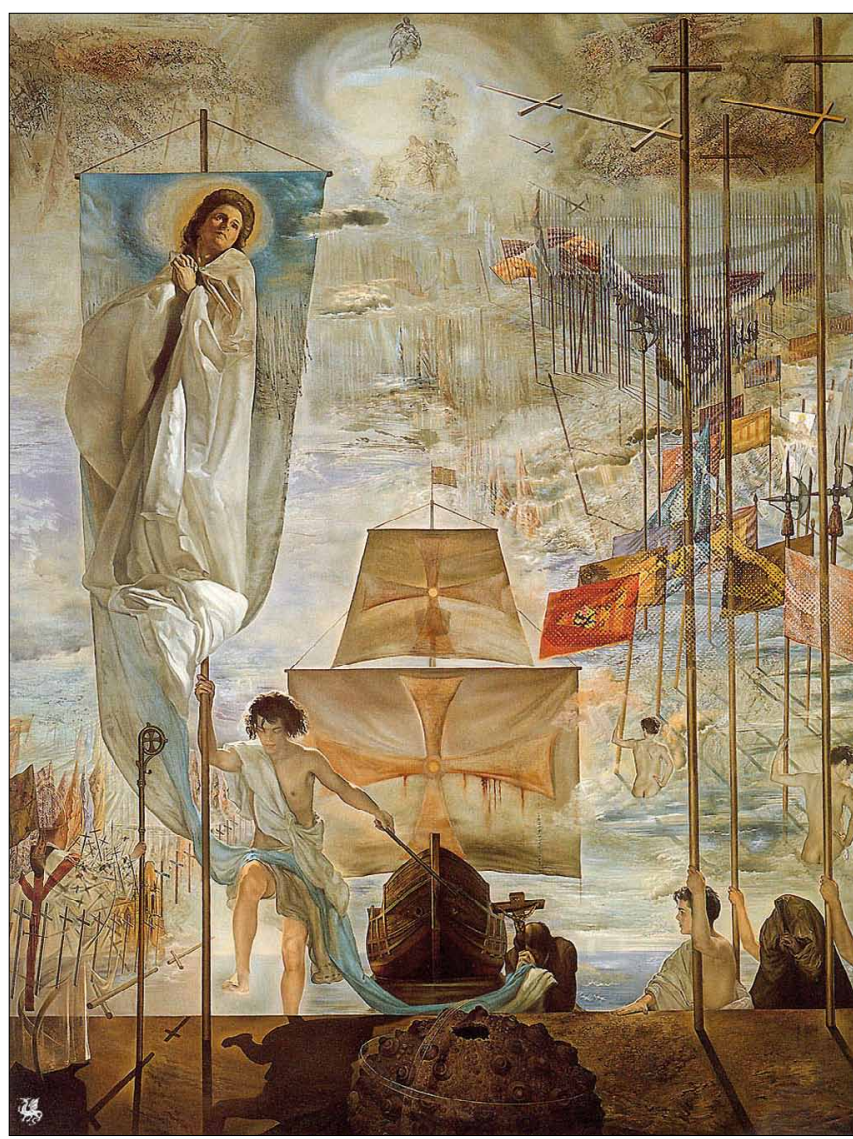

Fig. 13. Dali's The Discovery of America by Christopher Columbus (1959).

\section{NOTE}

In the early 1950s, both Salador Dali and Pierre Teilhard de Chardin were living in New York City. Dali's magnificent oil paintings of that decade unintentionally but vividly reflected Teilhard's mystical Roman Catholicism grounded in a converging planetary Christogenesis.

\section{ACKNOWLEDGEMENTS}

The preparation of this essay was inspired by the lasting influence of my distinguished professor Marvin Farber (19011980) and benefited from the thoughtful support of my dear friend Branko Milicevic in Belgrade. I am also deeply grateful to my colleagues Marko Bozovic, Prof. Dr. Ljiljana Markovic, and Ryan Trubits for their ongoing encouragement and help.

\section{SELECTED REFERENCES}

Aczel, Amir D. (2007): The Jesuit and the Skull: Teilhard de Chardin, Evolution, and the Search for Peking Man. New York, New York: Riverhead Books.

Alexander, Samuel (1966): Space, Time, and Deity. 2 vols. New York, New York: Dover Books. (Original work published 1920.)

Armstrong, Patrick H. (2007): All Things Darwin: An Encyclopedia of Darwin's World. 2 vols. Westport, Connecticut: Greenwood Press. 
Bergson, Henri (2007): Creative Evolution. New York, New York: Palgrave Macmillan. (Original work published 1907.)

Birx, H. James (2015): East \& West: Convergence \& Divergence, In: Vranes, A. \& L. Markovic, eds. Serbia between the East and the West. Belgrade, Serbia: University of Belgrade, Vol. 2, pp. 17-32.

Birx, H. James (2010): Evolution: As I See It. In: Anthropologia Integra, $1(2): 7-10$.

Birx, H. James (2010): Evolution: Science, Anthropology, and Philosophy. In: Birx, H. James, ed. 21 ${ }^{\text {st }}$ Century Anthropology: A Reference Handbook. Thousand Oaks, California: SAGE Publications, Vol. 2, pp. 586-599.

Birx, H. James (2009): Teilhard de Chardin, Pierre. In: Birx, H. James, ed. Encyclopedia of Time: Science, Philosophy, Theology, \& Culture. Thousand Oaks, California: SAGE Publications, Vol. 2, pp. 1223-1224.

Birx, H. James (2006): Teilhard de Chardin, Pierre. In: Birx, H. James, ed. Encyclopedia of Anthropology. Thousand Oaks, California: SAGE Publications, Vol. 5, pp. 2168-2171.

Birx, H. James (1997): God or Evolution? The Darwin-Wallace Schism. In: The Journal for the Critical Study of Religion, Ethics, and Society, 2(1):95110.

Birx, H. James (1997): Teilhard and Tipler: Critical Reflections. In: Modern Spiritualities: An Inquiry. Amherst, New York: Prometheus Books, pp. 209-222.

Birx, H. James (1996): Fossil Hominids and Our Own Species. In: Molina, Eustoquio, ed. Evolucion: Aspectos Interdisciplinares. Zaragoza, Spain: SIUZ/MIRA, No. 6, pp. 227-242.

Birx, H. James (1991): Interpreting Evolution: Darwin \& Teilhard de Chardin. Amherst, New York: Prometheus Books, esp. pp. 178-222.

Birx, H. James (1989): Darwin \& Teilhard: Some Final Thoughts. In: Proteus: A Journal of Ideas, Fall, 8(2):38-46.

Birx, H. James (1988): Human Evolution. Springfield, Illinois: Charles C Thomas.

Birx, H. James (1984): Theories of Evolution. Springfield, Illinois: Charles C Thomas, esp. pp. 209-222.

Birx, H. James (1981-1982): Teilhard and Evolution: Critical Reflections. In: Humboldt Journal of Social Relations, Fall/Winter, 9(1):151-167.

Birx, H. James (1972): Pierre Teilhard de Chardin's Philosophy of Evolution. Springfield, Illinois: Charles C Thomas.

Boaz, Noel T. \& Russel L. Ciochon (2004): Dragon Bone Hill: An Ice-Age Saga of Homo erectus. Oxford, UK: Oxford University Press, pp. 17-19, 23, 27 , 29, 32, 35, 37, 52, 97, 99-100, 112-113, 116, 173.

Braidotti, Rosi (2013): The Posthuman. Cambridge, UK: Polity Press.

Carr, Bernard (2007): Universe or Multiverse? Cambridge, UK: Cambridge University Press.

Chambers, Robert (1969): Vestiges of the Natural History of Creation. New York, New York: Humanities Press. (Original work published 1844.)

Chu, Ted (2013): Our Posthuman Future: Evolution, Transhumanism, and Human Purpose. San Rafael, California: Origin Press.

Condorcet, Marquis de (1955): Sketch for a Historical Picture of the Progress of the Human Mind. New York, New York: Noonday Press. (Original work published 1995.)

Coyne, Jerry A. (2009): Why Evolution is True. New York, New York: Viking Press.

Craig, William Lane \& James Porter Morehead, eds. (2009): The Blackwell Companion to Natural Theology. Chichester, UK: Wiley-Blackwell.

Cuenot, Claude. (1965): Teilhard de Chardin: A Biographical Study. Baltimore, Maryland: Helicon Press.

Dart, Raymond A. (1953): The Predatory Transition from Ape to Man. In: International Anthropological and Linguistics Review, 1(4):201-217.

Darwin, Charles (2000): The Voyage of the Beagle. Amherst, New York: Prometheus Books. Refer to the Introduction by H. James Birx, pp. vii-xxii. (Original work published 1839.)

Darwin, Charles (1998): The Descent of Man. Amherst, New York: Prometheus Books. Refer to the Introduction by H. James Birx, pp. ix-xxvii. (Original work published 1871.)

Darwin, Charles (1969): The Autobiography of Charles Darwin: 1809-1882. Barlow, Nora, ed. New York, New York: W.W. Norton. (Original work published 1887, unexpurgated version published 1958.)

Darwin, Charles (1859): On the Origin of Species by Means of Natural Selection: Or, the Preservation of Favored Races in the Struggle for Life. London, UK: John Murray.
Dawkins, Richard (2009): The Greatest Show on Earth: The Evidence for Evolution. New York, New York: Free Press.

Delio, Ilia, ed. (2014): From Teilhard to Omega: Co-creating an Unfinished Universe. Maryknoll, New York: Orbis Books.

Dennett, Daniel C. (1995): Darwin's Dangerous Idea: Evolution and the Meanings of Life. New York, New York: Simon \& Schuster.

Dewey, John (1965): The Influence of Darwin on Philosophy, and Other Essa$y$ s in Contemporary Thought. Bloomington, Indiana: Indiana University Press. (Original essay written 1909, published 1910.)

Dobzhansky, Theodosius (1967): The Biology of Ultimate Concern. New York, New York: New American Library.

Dodson, Edward O. (1984): The Phenomenon of Man Revisited: A Biological Viewpoint on Teilhard de Chardin. New York, New York: Columbia University Press.

Duffy, Kathleen (2014): Teilhard's Mysticism: Seeing the Inner Face of Evolution. Marykoll, New York: Orbis Books.

Fabel, Arthur \& Donald St. John, eds. (2003): Teilhard in the 21st Century: The Emerging Spirit of Earth. Maryknoll, New York: Orbis Books.

Farber, Marvin (1968): Basic Issues of Philosophy: Experience, Reality, and Human Values. New York, New York: Harper Torchbooks, esp. pp. 213-235.

Farber, Marvin (1968): Naturalism and Subjectivism. Albany, New York: State University of New York Press. (Original work published 1959.)

Feuerbach, Ludwig (1966): Principles of the Philosophy of the Future. New York, New York: Bobbs-Merrill. (Original work published 1843.)

Fix, William R. (1984): The Bone Peddlers: Selling Evolution. New York, New York: Macmillan, pp. 13, 113, 124, 126-129, 121-134, 138, 212, 246-247.

Fortey, Richard (1998): Life: A Natural History of the First Four Billion Years of Life on Earth. New York, New York: Alfred A. Knopf.

Glick, Thomas F. \& David Kohn, eds. (1996): Charles Darwin on Evolution: The Development of the Theory of Natural Selection. Indianapolis, Indiana: Hackett.

Gore, Rick (1997): The Dawn of Humans: The First Steps. In: National Geographic, February, 191(2):72-99.

Gosse, Philip Henry (1857): Omphalos: An Attempt to Untie the Geological Knot. London, UK: John Van Voorst.

Green, Brian (2011): The Hidden Reality: Parallel Universes and the Deep Laws of the Cosmos. New York, New York: Alfred A. Knopf.

Green, Brian (1999): The Elegant Universe: Superstrings, Hidden Dimensions, and the Quest for the Ultimate Theory. New York, New York: W.W. Norton.

Griffin, David Ray (1989): God and Religion in the Postmodern World: Essays in Postmodern Theology. Albany, New York: State University of New York Press, pp. 69-82.

Haeckel, Ernst (1992): The Riddle of the Universe at the Turn of the Nineteenth Century. Amherst, New York: Prometheus Books. Refer to the Introduction by H. James Birx, pp. ix-xiv. (Original work published 1899.)

Hall, J. Storrs (2005): Nanofuture: What's Next for Nanotechnology. Amherst, New York: Prometheus Books.

Harris, John (2007): Enhancing Evolution: The Ethical Case for Making Better People. Princeton, New Jersey: Princeton University Press.

Harris, Marvin (1968): The Rise of Anthropological Theory: A History of Theories of Culture. New York, New York: Thomas Y. Crowell, esp. pp. $142-216$.

Hartshorne, Charles (1973): A Natural Theology for Our Time. La Salle, Illinois: Open Court.

Hawking, Stephen W. (1996): A Brief History of Time: From the Big Bang to Black Holes. New York, New York: Bantam Books.

Huxley, Julian S. (1992): Evolutionary Humanism. Amherst, New York: Prometheus Books. Refer to the Introduction by H. James Birx, pp. vii-xii, and Teilhard de Chardin by Julian Huxley, pp. 202-217.

Huxley, Julian S. (1957): New Bottles for New Wine. London, UK: Chatto \& Windus. Refer to Transhumanism pp. 13-17, and Evolutionary Humanism pp. 279-312.

Huxley, Thomas H. (1959): Evidence as to Man's Place in Nature. Ann Arbor, Michigan: University of Michigan Press. (Original work published 1863.)

Kauffman, Stuart (1995): At Home in the Universe: The Search for the Laws of Self-Organization and Complexity. Oxford, UK: Oxford University Press.

King, Ursula (1996): Spirit of Fire: The Life and Vision of Teilhard de Chardin. Maryknoll, New York: Orbis Books.

Klossowski, Pierre (1997): Nietzsche and the Vicious Circle. Chicago, Illinois: Chicago University Press. 
Kropotkin, Peter (1914): Mutual Aid: A Factor of Evolution. Boston, Massachusetts: Extending Horizons Books.

Kurzweil, Ray (2005): The Singularity Is Near: When Humans Transcend Biology. New York, New York: Penguin Books.

Larson, Edward J. (2004): Evolution: The Remarkable History of a Scientific Theory. New York, New York: Modern Library.

Leakey, Richard E.F. (1994): The Origin of Humankind. New York, New York: Basic Books/HarperCollins.

Lukas, Mary \& Ellen Lukas (1981): Teilhard. rev. ed. New York, New York: McGraw-Hill.

Manly, Steven L. (2011): Visions of the Multiverse. Pompton Plains, New Jersey: New Page Books.

Mayr, Ernest (2001): What Evolution Is. New York, New York: Basic Books.

McIntosh, Steve (2012): Evolution's Purpose: An Integral Interpretation of the Scientific Story of Our Species. New York, New York: Select Books.

Medawar, Peter B. (1988): The Limits of Science. Cambridge, UK: Cambridge University Press.

Medawar, Peter B. (1961): Critical Notice. In: Mind (Oxford University Press), 70(277):99-106

Milicevic, Branko (2012): Humans in the Cosmos! In: Birx, H. James, ed. Nietzsche \& 2001: A Space Odyssey. Belgrade, Serbia: University of Belgrade, pp. 42-43.

Mortier, Jeanne \& Marie-Louise Aboux, eds. (1966): Teilhard de Chardin Album. New York, New York: Harper \& Row.

Nietzsche, Friedrich (1993): Thus Spake Zarathustra. Amherst, New York: Prometheus Books. Refer to the Introduction by H. James Birx, pp. 1327. (Original work written 1883-1885.)

O’Meara, Thomas F. (2012): Vast Universe: Extraterrestrials and Christian Revelation. Collegeville, Minnesota: Liturgical Press/A Michael Glazier Book.

Paley, William (1963): Natural Theology. Indianapolis, Indiana: Bobbs-Merri1l. (Original work published 1802.)

Pearson, Keith Ansell (1997): Viroid Life: Perspectives on Nietzsche and the Transhuman Condition. London, UK: Routledge.

Rachels, James (1991): Created from Animals: The Moral Implications of Darwinism. Oxford, UK: Oxford University Press.

Renan, Joseph Ernest (1883): Philosophical Dialogues and Fragments. London, UK: Truber/Ludgate Hill. (Original work published 1876.)

Rubenstein, Mary-Jane (2014): Worlds without End: The Many Lives of the Multiverse. New York, New York: Columbia University Press.

Schmitz-Moormann, Nicole \& Karl Schmitz-Moormann (1971): Pierre Teilhard de Chardin: Scientific Works (1905-1955). 11 vols. Olten und Frieburg im Breisgau: Walter Verlag.

Smith, Wolfgang (2012): Theistic Evolution: The Teilhardian Heresy. Tacoma, Washington: Angelico Press.

Spencer, Herbert (1862-1893): Synthetic Philosophy. 10 vols. New York, New York: D. Appleton.

Stallings, A.E. \& Richard Jenkyns (2007): Lucretius: The Nature of Things. London, UK: Penguin Books.

Stenger, Victor J. (2014): God and the Multiverse: Humanity's Expanding View of the Cosmos. Amherst, New York: Prometheus Books.

Stenger, Victor J. (2013): God and the Atom: From Democritus to the Higgs Boson. Amherst, New York: Prometheus Books.

Stenger, Victor J. (2012): God and the Folly of Faith: The Incompatibility of Science and Religion. Amherst, New York: Prometheus Books.

Stenger, Victor J. (2011): The Fallacy of Fine-Tuning: Why the Universe Is Not Designed for Us. Amherst, New York: Prometheus Books.

Stenger, Victor J. (2009): Quantum Gods: Creation, Chaos, and the Search for Cosmic Consciousness. Amherst, New York: Prometheus Books.

Stenger, Victor J. (2007): God: The Failed Hypothesis (How Science Shows That God Does Not Exist). Amherst, New York: Prometheus Books.

Swimme, Brian Thomas \& Mary Evelyn Tucker (2011): Journey of the Universe. New Haven, Connecticut: Yale University Press.

Teilhard de Chardin, Pierre (2008): The Phenomenon of Man. rev. ed. New York, New York: Perennial/HarperCollins. (Original work written 19381940, published in France 1955.) Refer to the Introduction (1958) by Sir Julian Huxley, pp. 11-28.

Teilhard de Chardin, Pierre (2001): The Divine Milieu: An Essay on the Inner Life. rev. ed. New York, New York: Harper Torchbooks/HarperCollins/Perennial Classics. Refer to the Foreword by Pierre Leroy, S.J., pp. xiii-xlvii.
Teilhard de Chardin, Pierre (1978): The Heart of Matter. New York, New York: Harcourt Brace Jovanovich.

Teilhard de Chardin, Pierre (1975): Towards the Future. New York, New York: Harcourt Brace Jovanovich.

Teilhard de Chardin, Pierre (1971): The Activation of Energy. New York, New York: Harcourt Brace Jovanovich.

Teilhard de Chardin, Pierre (1969): Christianity and Evolution. New York, New York: Harcourt Brace Jovanovich.

Teilhard de Chardin, Pierre (1969): Human Energy. New York, New York: Harcourt Brace Jovanovich.

Teilhard de Chardin, Pierre (1968): Letters from Hastings 1908-1912. New York, New York: Herder \& Herder.

Teilhard de Chardin, Pierre (1968): Science and Christ. New York, New York: Harper \& Row.

Teilhard de Chardin, Pierre (1968): Writings in Time of War. New York, New York: Harper \& Row.

Teilhard de Chardin, Pierre (1966): Man's Place in Nature: The Human Zoological Group. New York, New York: Harper \& Row/HarperCollins/Perennial Classics. Refer to the Introduction by Bernard Wall, pp. 1-6 \& Preface by Jean Pivetau, pp. 7-9.

Teilhard de Chardin, Pierre (1966): The Vision of the Past. New York, New York: Harper \& Row.

Teilhard de Chardin, Pierre (1965): Building the Earth. Wilkes-Barre, Pennsylvania: Dimension Books.

Teilhard de Chardin, Pierre (1965): Hymn of the Universe. New York, New York: Harper \& Row.

Teilhard de Chardin, Pierre (1965): Letters from Egypt 1905-1908. New York, New York: Herder \& Herder.

Teilhard de Chardin, Pierre (1965): The Appearance of Man. New York, New York: Harper \& Row.

Teilhard de Chardin, Pierre (1965): The Making of a Mind: Letters from a Soldier-Priest 1914-1919. New York, New York: Harper \& Row.

Teilhard de Chardin, Pierre (1964): The Future of Man. New York, New York: Harper \& Row.

Teilhard de Chardin, Pierre (1962): Letters from a Traveler. New York, New York: Harper \& Row.

Tipler, Frank J. (1994): The Physics of Immortality: Modern Cosmology, God and the Resurrection of the Dead. New York, New York: Doubleday, pp. 9 , $110-116,185,305-327$.

Trubits, Ryan J. (2009): Hominid-Pongid Split. In: Birx, H. James, ed. Encyclopedia of Time: Science, Philosophy, Theology, \& Culture. Thousand Oaks, California: SAGE Publications, Vol. 2, pp. 675-677.

Unamuno y Jugo, Miguel de (2013): The Tragic Sense of Life. New York, New York: Dover Books. (Original work published 1912.)

Ussher, James (2007): The Annals of the World. Green Forest, Arizona: New Leaf Press/Master Books. (Original work published 1658.)

Velikovsky, Immanuel (1955): Earth in Upheaval. Garden City, New York: Doubleday.

Vernadsky, Vladimir I. (1998): The Biosphere. New York, New York: Copernicus/Springer Verlag. (Original work published 1926.)

Vitzthum, Richard C. (1995): Materialism: An Affirmative History and Definition. Amherst, New York: Prometheus Books.

Walsh, John Evangelist (1996): Unraveling Piltdown: The Science Fraud of the Century and Its Solution. New York, New York: Random House, pp. 128-148.

Watson, James D. (2005): DNA: The Secret of Life. New York, New York: Alfred A. Knopf.

Weidenreich, Franz (1946): Apes, Giants, and Man. Chicago, Illinois: University of Chicago Press.

Whitehead, Alfred North (1978): Process and Reality: An Essay in Cosmology. New York, New York: Free Press. (Original work published 1929.)

Whitehead, Alfred North (1967): Science and the Modern World. New York, New York: Free Press. (Original work published 1925.)

Whitehead, Alfred North (1964): The Concept of Nature. Cambridge, UK: Cambridge University Press. (Original work published 1920.)

Wilson, Edward O. (2013): The Social Conquest of Earth. New York, New York: W.W. Norton. 


\section{AUTHOR}

Birx, H. James (1. 6. 1941, Canandaigua, New York, USA) is an American anthropologist and philosopher, "exemplary" professor of anthropology at Canisius College, and a permanent distinguished visiting professor at the University of Belgrade. He has been an invited scholar at the Friedrich Schiller University-Jena, Masaryk University-Brno, Max Planck Institute for Evolutionary AnthropologyLeipzig, Moscow State University, St. Petersburg State University, State University of New York-Geneseo, University of Cambridge, University of Chicago, University of Zaragoza, and twice at Harvard University (among other universities). His research has taken him from the Galapagos Islands of Ecuador to Koobi Fora in Kenya. He wrote the award-winning work Theories of Evolution (1984), and edited and contributed to the award-winning 5-volume Encyclopedia of
Anthropology (2006), as well as to two critically-acclaimed sets: the 3-volume Encyclopedia of Time (2009) and the 2-volume 21st Century Anthropology: A Reference Handbook (2010). His professional publications include authoring 6 books, editing and contributing to 19 volumes, and writing over 400 essays, entries, chapters, reviews, articles, and introductions. Dr. H. James Birx is a member on the council of scholar advisors for Frank Frost's forthcoming 2-hour international documentary The Teilhard de Chardin Project, to be telecast in 2016. Birx will give a conference paper at both the Imperial College London in July and the University of Berkeley in October.

Contact: Professor H. James Birx, Canisius College, Anthropology Division, 2001 Main Street, Buffalo, New York 14208-1098 USA, e-mail: birxh@canisius.edu or University of Belgrade, Faculty of Philology/Rex Hotel, Belgrade, e-mail: belgradejim@hotmail.com 